https://doi.org/10.15407/scine16.06.046

GOLUBEK, A.V., and DRON', N.M.

Oles Honchar Dnipro National University,

72, Gagarina Ave., Dnipro, 49010, Ukraine,

+38056374 9822, cdep@dnu.dp.ua

\title{
LAUNCH VEHICLE RENDEZVOUS WITH CATALOGUED ORBITAL DEBRIS WHILE INJECTING INTO HIGHLY-INCLINED ORBITS
}

Introduction. A constant increase in the amount of space debris already constitutes a significant threat to satellites in near-Earth orbits, starting with the trajectory of their launch vehicle injection.

Problem Statement. Design and development of various modern methods of protection against space debris requires knowledge of the statistical characteristics of the distribution of the kinematic parameters of the simultaneous motion of a launch vehicle injecting satellite and a group of space debris objects in the area of its trajectory.

Purpose. Development of a mathematical model of a launch vehicle rendezvous with a group of observable orbital debris while injecting a satellite into near-earth orbits with an altitude of up to $2100 \mathrm{~km}$ and an inclination from 45 to 90 degrees.

Materials and Methods. The following methods are used in the research: analysis, synthesis, comparison, simulation modeling, statistical processing of experimental results, approximation, correlation analysis, and the least squares method.

Results. The simultaneous motion of a launch vehicle and a group of space debris objects has been studied. The distributions of relative distance, relative velocity, angle of encounter, and moments of time of approach of a launch vehicle to a group of the observed space debris at a relative distance of less than $5 \mathrm{~km}$ have been obtained. The dependence of the average rendezvous concentration on the distribution of space debris across the average altitude of the orbit and the inclination of the target orbit of the launch vehicle has been determined. The dependence of the average probability of rendezvous in the launch on the inclination of the target orbit, the number of orbital debris, and the relative distance of the rendezvous has been determined.

Conclusions. The obtained mathematical model of rendezvous of a launch vehicle with a group of observed orbital debris can be used while designing means of cleaning the near-Earth space and systems to protect modern satellite launch vehicles from orbital debris. In addition, the results of the research can be used to assess the impact of unobserved orbital debris on the flight of a launch vehicle.

Keywords: launch vehicle, catalogued orbital debris, mutual motion, and model.

Citation: Golubek, A.V., and Dron', N.M. Launch Vehicle Rendezvous with Catalogued Orbital Debris while Injecting into Highly-Inclined Orbits. Sci. innov. 2020. V. 16, no. 6. P. 46-55. https://doi.org/10.15407/ scine16.06.046 
On April 12, 2019, the European Space Agency announced on its website the upper stage of the Atlas-5 launch vehicle collapsed between March 23 and 25, 2019, for unknown reasons. At the same time, the stage itself and about 40-60 small surrounding objects larger than $30 \mathrm{~cm}$ were observed with the use of ground-based equipment. This collapse has further aggravated the difficult environmental situation with near-Earth space debris $(\mathrm{SD})$ that is a real threat to launch vehicles (LV).

Today, there are many ways to deal with space debris, such as removal of space objects from target orbits [2-4], reinforcement of aircraft body, various passive and active means of cleaning, and so on [5], which are realized, in particular, by autophage (self-devouring or self-eating) rockets that are cheaper and more environment friendly than conventional LVs, since they consume their own structures as fuel for the propulsion system $[4,6]$. The implementation of many above mentioned methods requires knowledge of the initial distributions of kinematic parameters of joint motion of a LV and observed space debris, as well as of the rendezvous time, from the opening of the start window, and the probability of approach to critical distances that correspond to collision. The considered problem is complicated by the fact that the distribution of oscillating parameters of space debris orbits has a complex character that evolves under the action of various perturbations. In addition, the probability of $\mathrm{LV}$ rendezvous with the observed space debris is rather small, less than 0.01 in annual equivalent [7-10]. So, the simulation of rendezvous requires significant time inputs. At the same time, assuming the proximity of distributions, data on the joint motion of the LV and the observed space debris can be extrapolated to unobserved objects.

The main areas of research related to the outlined issues cover the following:

- developing a model of joint launch of a launch vehicle and observed space debris in low-inclined orbits around the Earth [7], solar-synchronous orbits [8], equatorial orbits [9]. and orbits with an inclination of $45^{\circ}[10]$;
- developing of a model of spatial-temporal distribution of SD flow density [11];

- modeling the SD evolution [12-14];

- studying the space development processes [15];

- developing methods for maneuvering the target object from a potentially hazardous space debris, including estimating the collision probability and calculating the optimal diversion maneuver [16];

- modeling a collision of spacecraft and space debris [17-21];

- developing a simplified method for predicting mechanical conflicts between space objects [22];

- reviewing the existing methods for reducing the contamination of the near-Earth space [5]. The purpose of the author's research is to develop a mathematical model of a launch vehicle rendezvous with observed space debris while bringing satellites to Earth's orbits at an altitude of up to $2100 \mathrm{~km}$ with an inclination of 45 to $90^{\circ}$. To achieve this goal, the data for the problem under consideration have been formulated:

- main LV characteristics as part of: the aerodynamic and mass-inertial properties, the propulsion system characteristics, the layout scheme, the control system cyclograms, and the angular flight programs;

- near-circular target orbits of the LV at an altitude from 500 to $2100 \mathrm{~km}$, with an inclination of $45,60,75,82$, and $90^{\circ}$;

- characteristics of the LV launching point;

- LV launch time window;

- cataloged space environment.

To solve the outlined problem, it is necessary:

- to determine the distribution of the kinematic parameters of $\mathrm{LV}$ rendezvous with the observed space debris while bringing the payload to target orbits;

- to establish the dependence of the average concentration of hazardous approaches (to a relative distance less than $5 \mathrm{~km}$ ) on the inclination of the LV target orbit and on the space debris distribution along the average orbit altitude;

- to establish the dependence of the average probability of hazardous approaches on the inclination of the target orbit, the number of 


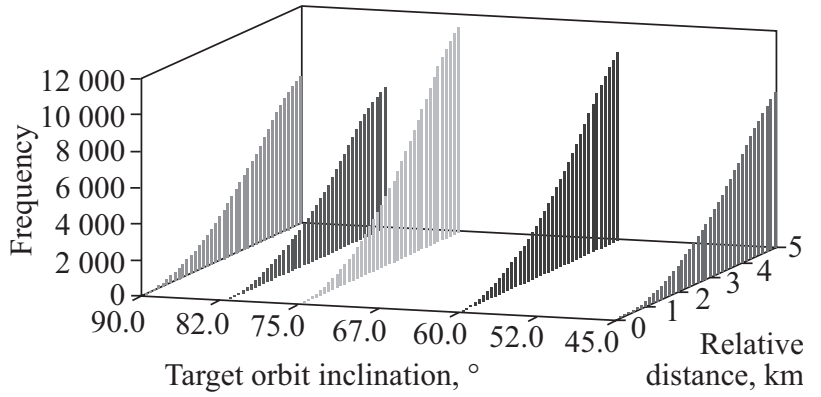

Fig. 1. Distribution of the number of hazardous rendezvouses by relative distance

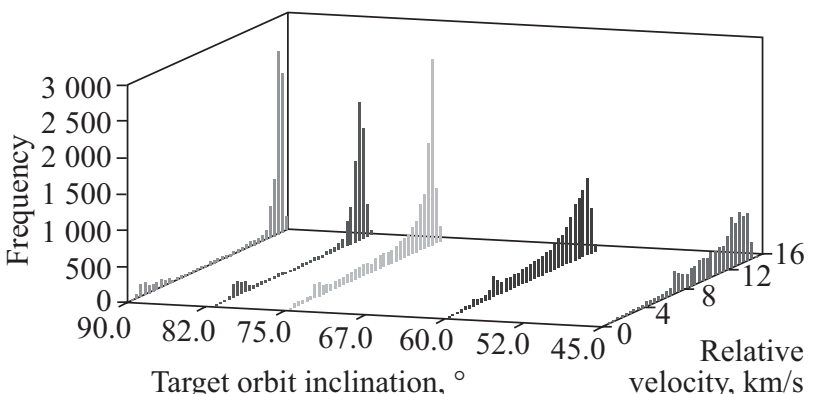

Fig. 2. Distribution of the number of hazardous rendezvouses by relative velocity

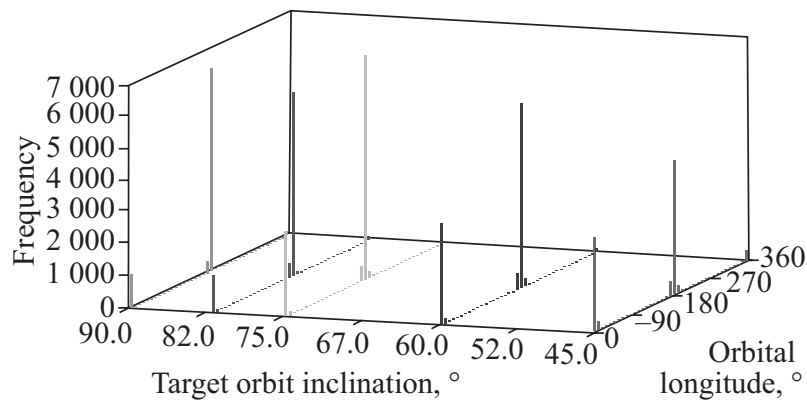

Fig. 3. Distribution of the number of hazardous rendezvouses by orbital longitude

space debris and the relative distance of the $\mathrm{LV}$ rendezvous with space debris.

Let us assume as follows:

- GOST 4401-81 (for the calculation of the active section of the LV trajectory) applies to Earth's atmosphere up to a height of $120 \mathrm{~km}$; above this height, GOST 25645.115-84 applies;

- The gravitational potential of the Earth takes into account the influence of 2,3 , and 4 zonal harmonics;

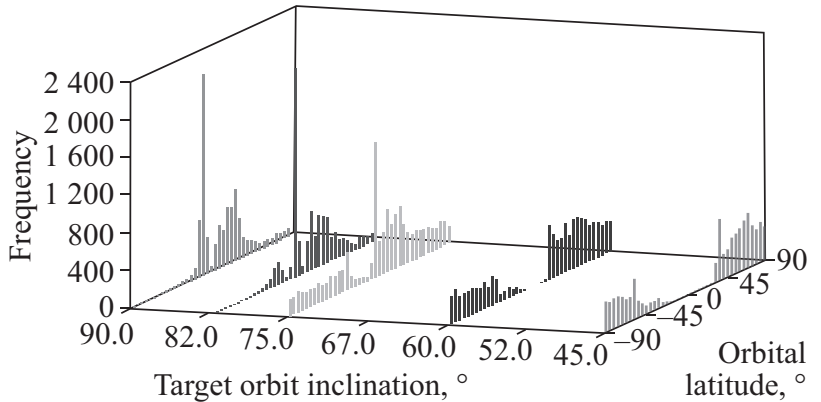

Fig. 4. Distribution of the number of hazardous rendezvouses by orbital latitude

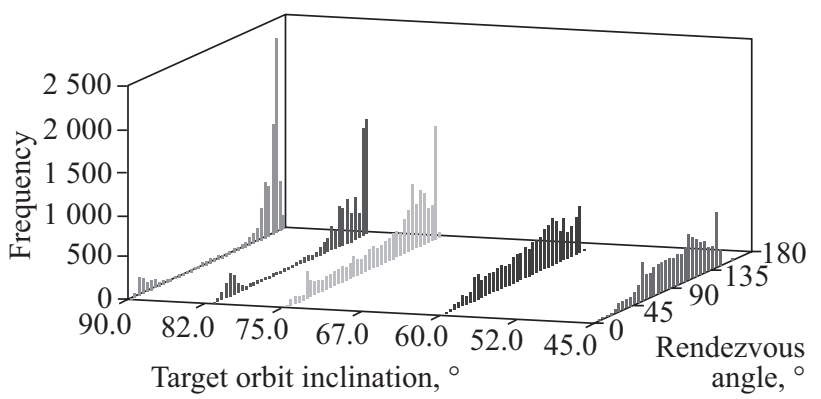

Fig. 5. Distribution of the number of hazardous rendezvouses by rendezvous angle

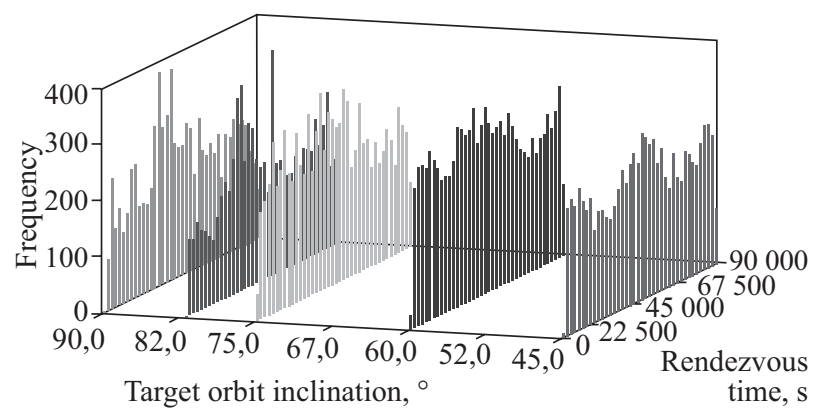

Fig. 6. Distribution of the number of hazardous rendezvouses by time interval from opening launch window till rendezvous

- The LV trajectory is built according to the twopulse scheme of the propulsion system, from the moment of the exit from the dense layers of the atmosphere (at an altitude of $120 \mathrm{~km}$ ) to the moment of the satellite separation in the target orbit;

- The space debris for which the perigee altitude is below the upper limit of the dense layers of the atmosphere is considered to have ceased to exist; 
- The number of space debris objects in the considered launch window is constant;

- The space debris is passive and does not maneuver to change the orbit;

- The LV and the space debris are material points;

- The LV rendezvous with space debris at a relative distance of less than $5 \mathrm{~km}$ is considered hazardous.

The initial conditions are a hypothetical light LV described in [23], with the launching point at the Alcantara Cosmodrome (Brazil) and the space catalog NORAD dated 20.06.2013. Given a low probability of rendezvous that for the spacecraft makes up 0.01 annually, at a relative distance of $10 \mathrm{~m}$ [1], to obtain more statistics on the joint motion, a daily launch window lasts from 00:00:00 21.06.2013 to 00:00:00 22.06.2013.

Let us consider the joint motion of the LV and the observed space debris in a deterministic formulation, with the use of the model given in [7]; the orientation angles are determined according to the recommendations [24-26], in the area of functional guidance, and with the use the multistep adaptive algorithm, in the terminal area [26].

The simulation is made according to the following scheme. There are given the altitude of the target orbit ranging from 500 to $2100 \mathrm{~km}$ with a step of $200 \mathrm{~km}$ and its inclination. For the selected target orbit, the nominal trajectory of orbiting is calculated and the data of the space catalog at the time of opening the launch window are predicted. Then, starting with the moment of opening the window, with a step of $1 \mathrm{~s}$, the launch time is selected and the joint motion of the LV and the observed space debris is simulated. Totally, 86,600 launches have been simulated for each orbit under consideration.

As a result of simulation of the LV flight and behavior of the observed space debris under selected initial conditions, the histograms of distribution of the main kinematic parameters of hazardous rendezvous (relative distance, relative velocity, orbital longitude, orbital latitude, rendezvous angle, and time interval from opening the window till the rendezvous) have been obtained (Figs. 1-6).
The statistical data of the main parameters of hazardous rendezvous are given in Tables 1-6.

Based on the results, one may conclude as follows. The largest number of hazardous rendezvouses is observed at a speed above $9 \mathrm{~km} / \mathrm{s}$ (Fig. 2), at a rendezvous angle $>90^{\circ}$ (Fig. 5). Rendezvouses mainly occur when the objects move in opposite or in-trail directions (Fig. 3). As the inclination of the orbit increases, so does the ratio between the number of frontal and in-trail rendezvouses. In addition, more rendezvouses are reported in the case of a positive orbital latitude than in the case of a negative one (Fig. 4). In the range of inclination $<60^{\circ}$, rendezvouses are observed at an orbital latitude larger than $30^{\circ}$ in absolute magnitude relative to the plane of the LV orbit. As inclination increases, there is a gradual growth in the number of rendezvouses at an angle $<30^{\circ}$.

The distribution of hazardous rendezvouses by the rendezvous time (Fig. 6) is close to a uniform one, which is confirmed by the obtained statistical parameters (Table 6), but according to Pearson's criterion $\chi^{2}$ it is not uniform.

It should be noted that the distributions of the parameters of hazardous rendezvouses depend on the inclination of the LV target orbit. The correlation analysis has showed that the first and second central moments of relative distance, relative velocity, orbital longitude and rendezvous angle, as well as the spread of the distributions of relative velocity and rendezvous angle depend on the inclination of the LV target orbit. The second central moment of distributions of orbital latitude and the rendezvous time, as well as the spread of distribution of rendezvous angle also depends on the inclination.

Having compared the obtained results with the area of low-inclined orbits, it should be noted the mathematical expectation of relative velocity, orbital longitude, and rendezvous angle shows a monotonous growth. In addition, the standard deviation of orbital longitude, orbital latitude, and rendezvous time decreases, while the standard deviation of relative velocity and rendezvous angle 
increases. Also it should be pointed out that the spread of the distribution of the relative velocity and the rendezvous angle insignificantly depends on the inclination of the target orbit, which is not observed for the orbits with an inclination $<45^{\circ}$.

It should be noted that there is a functional relationship between the relative velocity and the rendezvous angle, which is also observed for the low-inclined orbits [7]. The correlation coefficient

Table 1. Parameters of Distribution of the Number of Hazardous Rendezvouses by Relative Distance

\begin{tabular}{|c|c|c|c|c|}
\hline \multirow{2}{*}{$\begin{array}{c}\text { Target } \\
\text { orbit } \\
\text { inclination, }\end{array}$} & \multicolumn{4}{|c|}{ Parameters by relative distance, $\mathrm{km}$} \\
\cline { 2 - 5 } & $\mathrm{ME}$ & $\mathrm{StD}$ & $\min$ & $\max$ \\
\hline 45 & 3.207 & 1.157 & 0.015 & 5.000 \\
60 & 3.205 & 1.159 & 0.007 & 5.000 \\
75 & 3.177 & 1.131 & 0.031 & 5.000 \\
82 & 3.087 & 1.131 & 0.060 & 5.000 \\
90 & 3.096 & 1.130 & 0.031 & 4.999 \\
\hline
\end{tabular}

Note. Hereinafter: ME is mathematical expectation; StD is standard deviation; min, max are minimum and maximum values of parameter, respectively.

Table 2. Parameters of Distribution of the Number of Hazardous Rendezvouses by Relative Velocity

\begin{tabular}{|c|c|c|c|c|}
\hline \multirow{2}{*}{$\begin{array}{c}\text { Target } \\
\text { orbit } \\
\text { inclination, }\end{array}$} & \multicolumn{4}{|c|}{ Parameters by relative velocity, km/s } \\
\cline { 2 - 5 } & $\mathrm{ME}$ & $\mathrm{StD}$ & $\min$ & $\max$ \\
\hline 45 & 10.591 & 2.787 & 0.869 & 15.830 \\
60 & 10.986 & 3.300 & 0.473 & 15.976 \\
75 & 11.776 & 3.782 & 0.327 & 16.165 \\
82 & 12.534 & 4.176 & 0.412 & 15.907 \\
90 & 12.856 & 4.015 & 0.448 & 15.668 \\
\hline
\end{tabular}

Table 3. Parameters of Distribution of the Number of Hazardous Rendezvouses by Orbital Longitude

\begin{tabular}{|c|c|c|c|c|}
\hline \multirow{2}{*}{$\begin{array}{c}\text { Target } \\
\text { orbit } \\
\text { inclination, }\end{array}$} & \multicolumn{4}{|c|}{ Parameters by orbital longitude, } \\
\cline { 2 - 5 } & $\mathrm{ME}$ & $\mathrm{StD}$ & $\min$ & $\max$ \\
\hline 45 & 124.630 & 99.358 & 0.011 & 359.991 \\
60 & 129.406 & 91.194 & 0.002 & 359.997 \\
75 & 141.964 & 83.405 & 0.002 & 359.999 \\
82 & 157.583 & 71.538 & 0.000 & 359.978 \\
90 & 161.940 & 67.813 & 0.004 & 359.998 \\
\hline
\end{tabular}

between these two parameters weakly depends on the inclination of the target orbit and exceeds 0.97 (Fig. 7).

The analysis results have showed that the analytical expression proposed in [7] to approximate this dependence may also apply to the area of high-inclined orbits (its coefficients are obtained by the least squares method and are slightly different from the previously obtained values). The approximation dependence is shown in Fig. 7

Table 4. Parameters of Distribution of the Number of Hazardous Rendezvouses by Orbital Latitude

\begin{tabular}{|c|c|c|c|c|}
\hline \multirow{2}{*}{$\begin{array}{c}\text { Target } \\
\text { orbit } \\
\text { inclination, }^{\circ}\end{array}$} & \multicolumn{4}{|c|}{ Parameters by orbital latitude, } \\
\cline { 2 - 5 } & ME & StD & $\min$ & $\max$ \\
\hline 45 & 13.791 & 63.153 & -89.956 & 89.932 \\
60 & 12.525 & 56.552 & -89.889 & 89.969 \\
75 & 8.905 & 45.894 & -89.882 & 89.769 \\
82 & 14.695 & 26.358 & -87.908 & 89.001 \\
90 & 9.290 & 26.255 & -89.488 & 89.885 \\
\hline
\end{tabular}

Table 5. Parameters of Distribution of the Number of Hazardous Rendezvouses by Rendezvous Angle

\begin{tabular}{|c|c|c|c|c|}
\hline \multirow{2}{*}{$\begin{array}{c}\text { Target } \\
\text { orbit } \\
\text { inclination, }\end{array}$} & \multicolumn{4}{|c|}{ Parameters by rendezvous angle, } \\
\cline { 2 - 5 } & ME & StD & $\min$ & $\max$ \\
\hline 45 & 95.607 & 31.736 & 6.758 & 166.542 \\
60 & 102.930 & 39.027 & 2.849 & 163.849 \\
75 & 118.429 & 47.874 & 2.095 & 178.404 \\
82 & 135.842 & 52.616 & 2.739 & 179.767 \\
90 & 139.612 & 49.573 & 3.314 & 178.779 \\
\hline
\end{tabular}

Table 6. Parameters of Distribution of the Number of Hazardous Rendezvouses by Time Interval from Opening of the Launch Window till Rendezvou

\begin{tabular}{|c|c|c|c|c|}
\hline \multirow{2}{*}{$\begin{array}{c}\text { Target } \\
\text { orbit } \\
\text { inclination, }\end{array}$} & \multicolumn{4}{|c|}{ Parameters by rendezvous time, s } \\
\cline { 2 - 5 } & ME & StD & $\min$ & $\max$ \\
\hline 45 & 45795 & 24854 & 1820 & 89653 \\
60 & 44427 & 24666 & 1346 & 90197 \\
75 & 43309 & 23797 & -2276 & 90219 \\
82 & 46614 & 23209 & 2225 & 89834 \\
90 & 45993 & 23210 & 2176 & 90424 \\
\hline
\end{tabular}


with the bold blue line, its appearance is described by equation [7]:

$\widetilde{\alpha}=8.2 \cdot 10^{-3} \Delta V-2.5 \cdot 10^{-7} \Delta V^{2}+2.81 \cdot 10^{-11} \Delta V^{3}$, where $\widetilde{\alpha}$ is approximated rendezvous angle, ${ }^{\circ} ; \Delta V$ is relative rendezvous velocity, $\mathrm{m} / \mathrm{s}$.

Further, the dependence of the average concentration of hazardous rendezvouses on the flight altitude and the inclination of the target orbit has been studied using the method proposed in [7]. The dependences of the average concentration of hazardous rendezvouses per unit of time obtained for each orbit inclination are shown in Fig. 8 and superimposed on the histogram of the distribution of space debris by average altitude in low Earth orbits, based on the NORAD catalog.

From the obtained results it follows that the function of the average concentration of hazardous rendezvouses is similar to the distribution of space debris by altitude. The main difference between the dynamics of its change relative to the low-inclined orbits [7] is the presence of the two extremes: a maximum in the area of orbits with an inclination of $75^{\circ}$ and a minimum in the area of inclinations of $82-90^{\circ}$. Up to an inclination of $75^{\circ}$, the average concentration of hazardous rendezvouses increases monotonically. It is also necessary to mention that the obtained estimates are in good agreement with the data on the average concentration of space objects [1, 11-13]. In addition, the obtained dependence of the average concentration on the inclination of the target orbit strongly correlates with the dependence of the space debris flow coefficient per year $\psi$, as given in [24].

The correlation analysis has shown a functional dependence of the average concentration of hazardous rendezvouses on the flight altitude and

Table 7. Dependence of Weight Factor on the Average Concentration of Hazardous Rendezvouses on the Target Orbit Inclination

\begin{tabular}{|c|c|c|c|c|c|}
\hline Target orbit inclination, $^{\circ}$ & 45 & 60 & 75 & 82 & 90 \\
\hline Weight factor, $10^{-11} \mathrm{~km}^{-3}$ & 2.97 & 3.58 & 4.52 & 2.37 & 2.37 \\
\hline
\end{tabular}

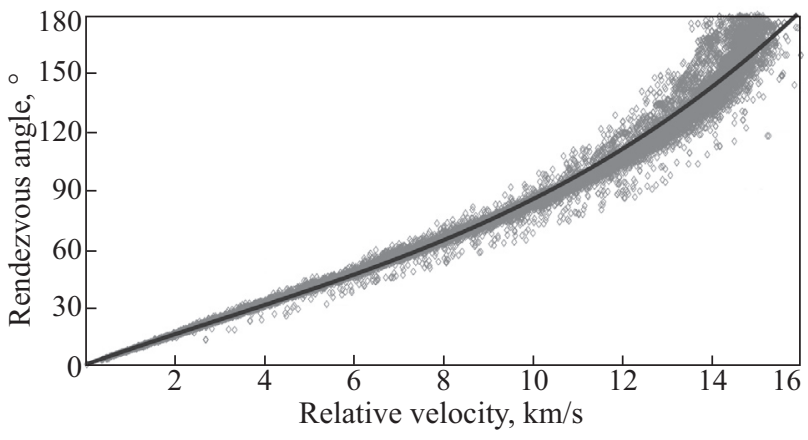

Fig. 7. Approximation of the dependence of rendezvous angle on relative velocity of hazardous rendezvous

on the altitude distribution of the observed space debris for each orbit inclination. Let us determine it with the use of the approximation of the histogram of the distribution of the observed space debris by the average orbit altitude $h$, as presented in [7]:

$$
\begin{gathered}
H=\frac{10^{-4} N_{K O}}{\sqrt{2 \pi}}\left\{15 \exp \left[\frac{(h-1451)^{2}}{6779}\right]+\right. \\
\left.+6 \exp \left[\frac{(h-1166)^{2}}{301967}\right]+51 \exp \left[\frac{(h-795)^{2}}{35471}\right]\right\},
\end{gathered}
$$

where $N_{K O}$ is the number of observed space debris, $N_{K O}=10837$.

Let us introduce assumptions about the linearity of the dependence in the considered range of altitudes and determine the approximating function. Using the method proposed in [7], we can calculate the dependence of the coefficient of the average concentration of hazardous rendezvouses on the inclination of the target orbit within the range under consideration (Table 7 ).

The dependence may be presented as polynomial:

$$
\begin{gathered}
n_{p}=3.815530 \cdot 10^{-16} i^{4}-1.047082 \cdot 10^{-13} i^{3}+ \\
+1.052741 \cdot 10^{-11} i^{2}-4.586309 \cdot 10^{-10} i+ \\
+7.327003 \cdot 10^{-9}
\end{gathered}
$$

where $n_{p}$ Bis weight factor, $\mathrm{km}^{-3} ; i$ is target orbit inclination, ${ }^{\circ}$.

From the above it follows that the average concentration of hazardous rendezvouses depends on altitude and inclination of target orbit, as well as 


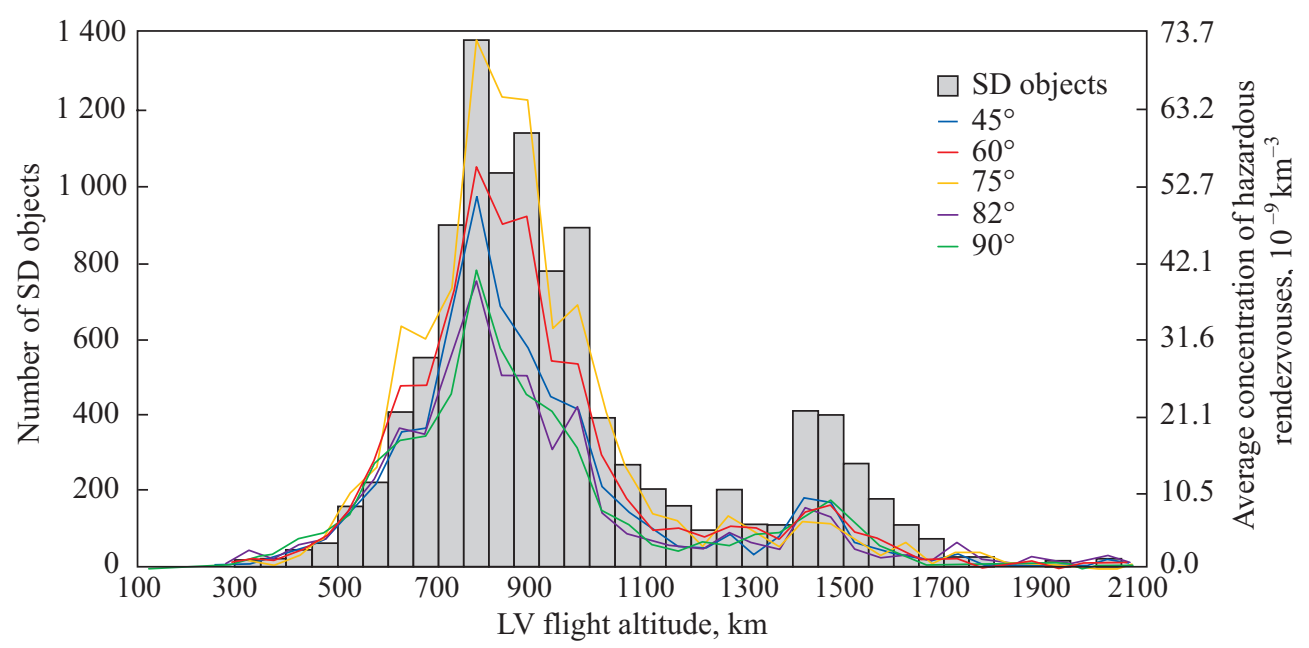

Fig. 8 . Histogram of the distribution of the number of space debris by average orbit altitude and the dependence of average concentration of hazardous rendezvouses on launch vehicle flight altitude

on the number of observed space debris:

$$
\begin{gathered}
n_{p}=\left(3.815530 \cdot 10^{-7} i^{4}-1.047082 \cdot 10^{-4} i^{3}+\right. \\
\left.+1.052741 \cdot 10^{-2} i^{2}-4.586309 \cdot 10^{-1} i+7.327003\right) \times, \\
\times \frac{10^{-13} N_{K O}}{\sqrt{2 \pi}}\left\{15 \exp \left[-\frac{(h-1451)^{2}}{6779}\right]+\right. \\
\left.+6 \exp \left[-\frac{(h-1166)^{2}}{301967}\right]+51 \exp \left[-\frac{(h-795)^{2}}{35471}\right]\right\} .
\end{gathered}
$$

It should be noted that the simulation results have confirmed the possibility of LV rendezvous with cataloged space debris not only at a relative distance of less than $100 \mathrm{~m}$, but also at a distance of less than $10 \mathrm{~m}$. Thus, one approximation for a relative distance of $7 \mathrm{~m}$ has been obtained.

\section{Table 8. Dependence of the Average Rendezvous \\ Probability at a Relative Distance Less Than $100 \mathrm{~m}$ on the Target Orbit Inclination}

\begin{tabular}{|c|c|c|c|c|}
\hline \multirow{2}{*}{$\begin{array}{c}\text { Target } \\
\text { orbit } \\
\text { inclina- } \\
\text { tion, }^{\circ}\end{array}$} & $\begin{array}{c}\text { Number of } \\
\text { rendezvouses } \\
\text { at a distance } \\
\text { less than } \\
100 \mathrm{~m}\end{array}$ & \multicolumn{3}{|c|}{$\begin{array}{c}\text { Probability of rendezvouses } \\
\text { at a relative distance }\end{array}$} \\
\cline { 3 - 5 } & $\begin{array}{c}\text { Less } \\
\text { than } 1 \mathrm{~m}\end{array}$ & $\begin{array}{c}\text { Less } \\
\text { than } 10 \mathrm{~m}\end{array}$ & $\begin{array}{c}\text { Less } \\
\text { than } 100 \mathrm{~m}\end{array}$ \\
\hline 45 & 3 & $3.9 \times 10^{-8}$ & $3.9 \times 10^{-7}$ & $3.9 \times 10^{-6}$ \\
60 & 5 & $6.4 \times 10^{-8}$ & $6.4 \times 10^{-7}$ & $6.4 \times 10^{-6}$ \\
75 & 6 & $7.7 \times 10^{-8}$ & $7.7 \times 10^{-7}$ & $7.7 \times 10^{-6}$ \\
82 & 4 & $5.1 \times 10^{-8}$ & $5.1 \times 10^{-7}$ & $5.1 \times 10^{-6}$ \\
90 & 3 & $3.9 \times 10^{-8}$ & $3.9 \times 10^{-7}$ & $3.9 \times 10^{-6}$ \\
\hline
\end{tabular}

Based on the statistical data of rendezvous, given the number of simulated launches, which in the considered launch window and the range of target orbit altitudes totals 777600 , we have determined the average probability of LV rendezvous with cataloged space debris at a relative distance $<100 \mathrm{~m}$ (Table 8). Given that the dependence on the "tails" of the distributions is often close to linear, we have determined the rendezvous probability at a relative distance of $1 \mathrm{~m}$ and $10 \mathrm{~m}$.

The obtained dependence of the average rendezvous probability at a relative distance of $100 \mathrm{~m}$ and less is similar to the dependence of the weight factor of the concentration of hazardous rendezvouses on the target orbit inclination. The analysis has shown a significant dependence of these two functions (the correlation coefficient exceeds $0.8)$. At the same time, on the one hand, the dependence of the rendezvous probability on the concentration of hazardous rendezvouses is obvious, but on the other hand, the obtained statistical data on LV rendezvouses with space debris are limited to a relative distance of $100 \mathrm{~m}$ or less (the maximum number does not exceed six, at an inclination of $75^{\circ}$ ). Based on the above, the dependence of the average rendezvous probability 
at a distance of $100 \mathrm{~m}$ and less on the average concentration of hazardous rendezvouses is considered linear and is written as:

$$
\begin{gathered}
P_{C}=15.69 N_{K O}(1-\exp [-0.12 \Delta r]) n_{p}= \\
=15.69 N_{K O}(1-\exp [-0.12 \Delta r]) \times \\
\times\left(3.815530 \cdot 10^{-16} i^{4}-1.047082 \cdot 10^{-13} i^{3}+\right. \\
+1.052741 \cdot 10^{-11} i^{2}-4.586309 \cdot 10^{-10} i+ \\
\left.+7.327003 \cdot 10^{-9}\right),
\end{gathered}
$$

where $\Delta r$ is relative distance between $\mathrm{LV}$ and space debris, $\mathrm{m}$.

Given that for the considered LV and flight scheme, the time of the active section of the trajectory is about an hour, the rendezvous probability at a relative distance of less than $10 \mathrm{~m}$ ranges from 0.003 to 0.007 per year, depending on the target orbit inclination. It should be noted that these estimates are lower than the probability of collision of a space object larger than $10 \mathrm{~m}$ with cataloged space debris at an altitude of $800-$ $1000 \mathrm{~km}$, in 2000, which is 0.01 in annual equivalent [1]. At the same time, the probability of a $10 \mathrm{~m}$ diameter satellite approaching a space debris object in a synchronous orbit at an altitude of $800 \mathrm{~km}$, according to data obtained by Duncan Steel [14], is about 0.001 in annual equivalent.

To summarize, as a result of modeling, the distributions of relative distance, relative velocity, rendezvous angle, orbital latitude, orbital longitude, and rendezvous time for LV hazardous rendezvouses with observed space debris have been obtained. It has been established that the most hazardous rendezvouses are observed with relative velocities greater than $10 \mathrm{~km} / \mathrm{s}$, at a rendezvous angle larger than $110^{\circ}$; in the LV orbit plane, mostly, in the cases of motion in opposite or intrail direction; with respect to the orbit plane, the rendezvouses are more often above it than below.

The distributions of the rendezvous parameters have been shown to have a complex character, and the distributions of the relative distance, relative velocity, and rendezvous angle functionally depend on the target orbit inclination. It has been found that the distribution of hazardous rendezvouses by rendezvous time is close to uniform, which does not agree with Pearson's criterion $\chi^{2}$.

The calculations have shown that the dependence of the rendezvous angle obtained earlier in [7] on the relative velocity of hazardous rendezvouses for target low-inclined orbits is also valid for high-inclined orbits. The dependence of the average concentration of hazardous rendezvouses at a relative distance of less than $5 \mathrm{~km}$, depending on the target orbit inclination and the distribution of space debris on the average orbit altitude, has been determined. The average probability of hazardous rendezvouses at a relative distance of less than $100 \mathrm{~m}$ has been estimated. It has been shown the obtained estimates are in good agreement with the known results. The dependence of the average probability of hazardous rendezvouses on the target orbit inclination, the number of space debris objects and the relative distance of rendezvous has been established as well.

\section{REFERENCES}

1. Veniaminov, S. S. (2013). Space debris is a threat to humanity. Moscow [in Russian].

2. Dron', M., Golubek, A., Dubovik, L., Dreus, A., Heti, K. (2019). Analysis of ballistic aspects in the combined method for removing space objects from the near-earth orbits. Eastern-European Journal of Enterprise Technologies, 2/5(98), 49-54. doi: 10.15587/1729-4061.2019.161778.

3. Alpatov, A. P., Paliy, O. S., Skorik, O. D. (2017). The development of structural design and the selection of design parameters of aerodynamic systems for de-orbiting upper-stage rocket launcher. Sci. innoz., 13(4), 33-45. doi: 10.15407/ scin13.03.033.

4. Dron', N. M., Dubovik, L. G., Golubek, A. V., Dreus, A. Yu., Yemets, V. V., Pashkov, A. V. (2019). Systems for the removal of space objects from low earth orbits. Monograph. Dnipro [in Ukrainian].

5. Dron', N. M., Horolsky, P. G., Dubovik, L. G. (2014). Ways of reduction of technogenic pollution of the near-earth space. Scientific Bulletin of National Mining University, 3(141), 125-130 [in Russian].

6. Yemets, V., Harkness, P., Dron, M., Pashkov, A., Worrall, K., Middleton, M. (2018). Autophage engines: toward a throttleable solid motor. Journal of Spacecraft and Rockets, 55(4), 984-992. doi: 10.2514/1.A34153. 
7. Golubek, A. V. (2018). Launch vehicle rendezvous with cataloged space objects during insertion into orbits with low inclination. Proceedings of Higher Educational Institutions. Machine Building, 2(695), 86-98 [in Russian]. doi: 10.18698/ 0536-1044-2018-2-86-98.

8. Golubek, A. V. (2014). Investigation of mutual approaches of the launch vehicle in the active section of the trajectory with space objects. Journal of rocket-space technology, 4(22), 26-35 [in Russian].

9. Golubek, A. V. (2015). The characteristics of the rendezvous of the launch vehicle with space objects in injection into equatorial orbits analysis. Journal of rocket-space technology, 4(23), 32-41 [in Russian].

10. Golubek, A. V. (2016). The characteristics of the rendezvous of the launch vehicle with space objects in injection into orbits with inclination $45 \mathrm{deg}$ analysis. Journal of rocket-space technology, 4(24), 20-28 [in Russian].

11. GOST R 25645.167-2005. Space environment (natural and artificial). Model of spatial and time distribution for space debris flux density in LEO. Moscow, 2005. [in Russian].

12. Nazarenko, A. I. (2013). Modeling of space debris. Moscow [in Russian].

13. Klinkrad, H. (2006). Space Debris - Models and Risk Analysis. Springer-Verlag.

14. Steel, D. Assessment of the Orbital Debris Collision Hazard for Low-Earth Orbit Satellites. URL: http://www.duncansteel.com/archives/1425 (Last accessed: 22.04.19).

15. Anz-Meador, P. (2000). GEO Evolve 1.0: A Long-Term Debris Evolution Model for the Geosynchronous Belt. Orbital Debris. Quarterly News, 5-7. URL: http://www.orbitaldebris.jsc.nasa.gov/newsletter/pdfs/ODQNv5i4.pdf (Last accessed: 22.04.2019).

16. Patera, R. P. Patent of USA N 2004/0024527 A1. Vehicular trajectory collision conflict prediction method.

17. Firooz, A. A., Rongier, I., Wilde, P. D., Sgobba, T. (2013). Safety design for space operations. Elsevier Ltd.

18. Vittaldev, V. (2013). Collision probability for space objects using gaussian mixture models. Spaceflight mechanics, $148(13-351), 1-20$.

19. Serra, R., Arzelier, D., Joldes, M., Lasserre, J.-B., Rondepierre, A., Salvy, B. (2016). Fast and Accurate Computation of Orbital Collision Probability for Short-Term Encounters.Journal of Guidance, Control, and Dynamics, 39 (5), 1009 1021. doi: 10.2514/1.G001353.

20. Shelton, C. T., Junkins, J. L. (2019). Probability of collision between space objects including model uncertainty. Acta Astronautica, 155, 462-471. doi: 10.1016/j.actaastro.2018.11.051.

21. Alfano, S. (2006). Satellite Collision Probability Enhancements. Journal of Guidance, Control, and Dynamics, 29(3), 588592. doi: $10.2514 / 1.15523$.

22. Labutkina, T. V., Petrenko, A. N. (2013). A new aspect of modeling a multi-element system of orbital objects. Bulletin of the National Technical University "KhPI". A series of "Information and Modeling", 19, 60-74 [in Russian].

23. Igdalov, I. M., Kuchma, L. D., Poliakov, N. V., Sheptun, Yu. D. (2013). Dynamic designing of rockets. Dynamic problems of rockets and their space stages. Monograph. (Ed. S. N. Konyukhov). Dnipropetrovsk.

24. Adzhian, A. P., Akim, E. L., Alifanov, O. M., Andreev, A. N. (2012). Mechanical engineering encyclopedia. T. IV-22: Aerospace technology. Book 1. Moscow [in Russian].

25. Sikharulidze, Yu. G. (2011). Ballistics and homing of flying vehicles. Moscow. [in Russian].

26. Alekseev, Yu. S., Balabey, Yu. E., Baryshnikova, T. A. et. al. (2012). Design of control systems for objects of rocket and space technology. Vol. 1. Design of control systems for launch vehicles: Textbook. (Eds. Yu. S. Alekseev, Yu. M. Zlatkin, V. S. Krivtsov, A. S. Kulik, V. I. Chumachenko). Kharkov [in Russian].

Received 07.06.19

Revised 19.09.19

Accepted 07.11.19

\section{О.В. Голубек, М.М. Дронь}

Дніпровський національний університет імені Олеся Гончара,

просп. Гагаріна, 72, Дніпро, 49010, Україна,

+380 563749822 , cdep@dnu.dp.ua

ЗБЛИЖЕННЯ РАКЕТИ-НОСІЯ ЗІ СПОСТЕРЕЖУВАНИМИ

ОБ’ЄКТАМИ КОСМІЧНОГО СМІТТЯ В ПРОЦЕСІ ВИВЕДЕННЯ

НА ОРБІТИ З ВИСОКИМ НАХИЛЕННЯМ

Вступ. Постійне збільшення кількості космічного сміття становить суттєву загрозу польотам супутників на навколоземних орбітах, починаючи з дільниці їнього виведення ракетою-носієм. 
Проблематика. Проєктування та створення сучасних методів захисту від впливу космічного сміття потребує знання статистичних характеристик розподілу кінематичних параметрів сумісного руху ракети-носія, яка виводить супутник, і сукупності об’єктів космічного сміття в межах $\dddot{11}$ траєкторії.

Мета. Розробка математичної моделі зближення ракети-носія з сукупністю спостережуваних об’єктів космічного сміття в процесі виведення супутника на навколоземні орбіти висотою до 2100 км та нахиленням від 45 до $90^{\circ}$.

Матеріали і методи. Використано методи аналізу, синтезу, порівняння, імітаційного моделювання, а також статистичну обробку результатів, апроксимацію, кореляційний аналіз, метод найменших квадратів.

Результати. Досліджено сумісний рух ракети-носія і сукупності об'єктів космічного сміття. Отримано розподіли відносної відстані, відносної швидкості, кута зустрічі та моментів часу зближення ракети-носія з сукупністю спостережуваних об'єктів космічного сміття на відносну відстань менше 5 км. Визначено залежність середньої концентрації зближень від нахилення цільової орбіти та розподілу космічного сміття по середній висоті орбіти. Встановлено залежність середньої ймовірності зближень в запуску від нахилення цільової орбіти, кількості об'єктів космічного сміття і відносної відстані зближення.

Висновки. Отриману математичну модель зближення ракети-носія з сукупністю спостережуваного космічного сміття може бути використано в задачі проєктування засобів очищення навколоземного космічного простору, а також в процесі проєктування систем захисту сучасних ракет-носіїв, що виводять супутники, від впливу космічного сміття. Крім того, результати дослідження можна застосовувати й для оцінки впливу неспостережуваних об'єктів космічного сміття на політ ракети-носія.

Ключові слова: ракета-носій, спостережуване космічне сміття, сумісний рух, модель. 